\title{
Cultivars of Mabonia bealei (Fort.) Carr. as a source of potential natural product with anti-Alzheimer's Disease activity
}

\author{
Huang $\mathrm{Y}^{1,2 *}, \mathrm{Su} \mathrm{Y}^{1}$ and Wang $\mathrm{T}^{1 *}$ \\ ${ }^{1}$ Shenzhen Institute for Drug Control, Shenzhen 518057, China \\ ${ }^{2}$ Key Laboratory of Molecular Target \& Clinical Pharmacology and the State Key Laboratory of Respiratory Disease, School of Pharmaceutical Sciences \& the Fifth \\ Affiliated Hospital, Guangzhou Medical University, Guangzhou, Guangdong 511436, China
}

\begin{abstract}
The study aims to evaluate the anti-Alzheimer's Disease activity of methanol extracts obtained from wild Mahonia bealei (Fort.) Carr (M. bealei), cultivated M. bealei and its substitutes. Ellman method was applied to test the anti-acetylcholinesterase of those extracts. Neuroprotective activity was evaluated by reducing the toxicity of amyloid beta $_{1-40}\left(\mathrm{~A} \beta_{1-40}\right)$ in a PC12 cell model. Oxygen radical absorbance capacity (ORAC) assay was applied to evaluate their antioxidant activity. The RAW264.7 cells were treated with lipopolysaccharide and the levels of NO and TNF-a were measured by Griess reaction and ELISA kit for the anti-inflammatory activity. Five main compounds from the extracts were analyzed by HPLC in order to find a relation between these compounds and different extracts. those investigated effects of wild $M$. bealei and cultivated $M$. bealei extracts showed a higher stronger activity than its substitutes without detrimental effects on cell viability. Their activities results were not fully related to the contents of selected five alkaloids and demonstrated those effects were caused in a holistic way with its multiple components and multiple targets.
\end{abstract}

\begin{abstract}
Abbreviations: $\mathrm{AD}$ : Alzheimer's disease; $\mathrm{A} \beta$ : amyloid beta; AAPH: 2,2'-azobis (2-methyl-propanimidamide) dihydrochloride; ANOVA: one-way analysis of variance; ATChI: acetyl-thiocholine; AChE: acetyl-cholinesterase; AChEI: acetylcholinesterase inhibitor; ChEIs: cholinesterase inhibitors; DMSO: dimethyl sulfoxide; DTNB: 5,5-dithiobis-2-nitrobenzoic acid; FDA: food and drug administration; GLAH: galanthamine; $\mathrm{HCl}$ : hydrochloric acid; LPS: lipopolysaccharide; MTT: 3-(4,5-dimethyl- 2-thiazolyl)-2,5-diphenyl-2-H- tetrazolium bromide; M. bealei, Mahonia bealei (Fort.) Carr; M. breviracema Y. S.Wang et Hsiao (DX), Mahonia breviracema Y.S. Wang et Hsiao; M. duclouxiana Gagnep (CZ), Mahonia duclouxiana Gagnep; M. bodinieri Gagnep (XG), Mahonia bodinieri Gagnep; M. fordii Schneid (BJ), Mahonia fordii Schneid; MeOH: methanol; NO: Nitric Oxide; NMDA: N-methyl-D-aspartate; ORAC: Oxygen radical absorbance capacity; PC12: pheochromocytoma 12; PBS: phosphate buffer saline; SD: standard deviation; TCMs: traditional chinese medicines; TNF- $\alpha$ : tumor necrosis factor alpha; Trolox: 6-hydroxy-2,5,7,8-tetramethyl-2carboxylic acid; TE: trolox equivalents.
\end{abstract}

\section{Introduction}

Alzheimer's disease (AD) is a progressive neurodegenerative disorder, and people who have AD suffer from gradually neurons loss and cognitive decline [1]. In 2019, there are over 50 million people living with $\mathrm{AD}$ globally and it will increase to 152 million by 2050. The current annual cost of $\mathrm{AD}$ is estimated at one trillion US dollar. This figure set to double by 2030 according to the 2019 World Alzheimer Report produced by Alzheimer's Disease International [2]. This becomes a huge burden for our society and economy. At present, the cause of the $\mathrm{AD}$ is still uncertain, and the therapeutic intervention to stop the progression of the dementia is not available. It is urgent to understand the mechanism and prevent the progression of $\mathrm{AD}$, thereby patients' daily activity can be promoted. Multifaceted pathogenesis of $\mathrm{AD}$ have been reported, including excessive plaques of amyloid beta (A $\beta$ ) peptides hypothesis, impairment of cholinergic transmission hypothesis, chronic inflammation hypothesis, oxidative stress hypothesis, and tau protein hyperposphorylation hypothesis [3]. Two medications approved by US Food and Drug Administration (FDA) are cholinesterase inhibitors (ChEIs; e.g., donepezil and rivastigmine) and non-competitive N-methyl-D-aspartate (NMDA) receptor antagonists (e.g., memantine) [4]. However, the current AD treatment drugs are used for temporarily reducing symptoms focusing on moderate or severe $\mathrm{AD}$ with unknown underlying pathology [5]. Therefore, novel treatments that can prevent or delay the symptoms of $\mathrm{AD}$ or slow the progression of $\mathrm{AD}$ are in need.

Traditional Chinese medicines (TCMs) have been commonly used for treating memory impairment for a long history [6]. Alkaloids, flavonoids, ketones, etc. are suggested active ingredients from TCMs with broad benefits, including anti-oxidation, anti-AChE, anti-

${ }^{\star}$ Correspondence to: Huang Y, Xinzao, Panyu District, Guangzhou, 511436, China Tel: 020-37105181; Fax: +86-20-37105182, E-mail: huangyang@gzhmu.edu.cn

Wang T, No.28, High-tech Middle Road, Nanshan District, Shenzhen Institute for Drug Control, Shenzhen, 518057. Tel: +86-755-26031728; Fax: +86-75526031729, E-mail: szyjwtj@163.com

Key words: Alzheimer's disease, Mahonia bealei (Fort.) Carr, antiacetylcholinesterase, anti-amyloid beta, antioxidant, anti-inflammatory

Received: November 28, 2020; Accepted: December 18, 2020; Published: January 04, 2021 
inflammatory and protecting neurons from damage by $\mathrm{A} \beta$ peptide, etc. $[7,8]$. Fortunately, two well-known alkaloids, huperzine A and galantamine were successfully discovered and isolated from Huperzia serrata (Thunb. ex Murray) Trev., [9,10] and Lycoris radiata (L'Her.) Herb [11] for the treatment of $\mathrm{AD}$, indicating TCMs are promising source of new bioactive agents. However, it's integrity of TCMs ingredients and their combined effects are generally responsible for causing pharmacological or toxicological properties [12]. There is a possibility that single bioactive compounds isolated from TCMs extract sometimes weakened the effectiveness of whole component system. Recently, this viewpoint has been confirmed by our group. A fishing platform was developed to fish acetylcholinesterase inhibitor (AChEI) from Mahonia bealei (Fort.) Carr (M. bealei) extract. Four potential AChEIs (columbamine, jatrorrhizine, berberine, and palmatine) were successfully screened out and identified [13]. Moreover, it was found that the anti-AChE effect of $M$. bealei extract was much more active than any above-mentioned single AChEIs, and synergistic effects of these AChEIs were successfully verified. However, due to the features of multi-compound, multi-target of TCM (e.g. M. bealei), other targets except $\mathrm{AChE}$ for the treatment of $\mathrm{AD}$ have not been reported. Therefore, it's interesting to investigate the analysis of M. bealei studied for its anti$\mathrm{AD}$ activity from a holistic perspective.

M. bealei (Berberidanceae), as an important TCM, is recorded approximately 70 species of Mahonia genus growing around the world, and about 50 species of Mahonia in Chinas such as such as Mahonia breviracema Y.S. Wang et Hsiao (M. breviracema Y. S. Wang et Hsiao), Mahonia duclouxiana Gagnep ( $M$. duclouxiana Gagnep), Mahonia bodinieri Gagnep (M. bodinieri Gagnep), and Mahonia fordii Schneid (M. fordii Schneid) [14]. M. bealei was reported rich in alkaloids and exhibited a variety of biological activities, including anti-bacterial [15], anti-inflammatory [16], antioxidant [17], and anti-AChE [18] activities, etc. Basing on our previous studies, the wild $M$. bealei, cultivated $M$. bealei and its substitutes are widely existed in the market while a great quality difference was observed using supercritical fluid chromatography and chemical pattern recognition method [14]. As far as we know, little attention has been paid to their anti-AD activity.

In this study, wild M. bealei, cultivated M. bealei and its substitutes were selected to investigate for anti-AD activity particularly focusing on anti-AChE, anti-amyloid beta1-40 $\left(\mathrm{A} \beta_{1-40}\right)$ peptide, antioxidant and anti-inflammation effect. Thereafter, their differences in anti-AD activity were compared in order to ensure the consistence of their quality. In addition, several main alkaloids from those extracts were selected as determination in order to compare the relation of activities and the contents of alkaloids.

\section{Materials and methods}

\section{Chemicals and reagents}

The methanol $(\mathrm{MeOH})$ and dimethyl sulfoxide (DMSO) was obtained from Merck (Shanghai, China). Hydrochloric acid (HCl) was obtained from Guangzhou Chemical Reagent Factory (Guangzhou, China). Phosphate buffer saline (PBS) at pH 7.4 and Cell counting kit8 (CCK-8) was purchased from Beyotime Biotechnology (Shanghai, China). 96-well flat bottom polystyrenemicrotitre plates were obtained from Corning (Shanghai). 5,5-dithiobis-2-nitrobenzoic acid (DTNB) and acetyl-thiocholine (ATChI) were purchased from Aladdin Chemicals (Shanghai, China). Pheochromocytoma (PC12) cells were obtained from Shanghai Institute of Biochemistry and Cell Biology (Shanghai, China). RAW 264.7 cell line was obtained from Life Science College of Hongkong Chinese University. Tumor Necrosis Factor Alpha (TNF- $\alpha$ ) kit was purchased from Nanjing Jiancheng Bioengineering Institute (Nanjing, China). Micro-plate reader and Griess reagent
$[0.1 \% \quad(w / v) \quad \mathrm{N}$-(1-naphthyl)-ethylenediamine, with $1 \% \quad(\mathrm{w} / \mathrm{v})$ sulfanilamide in $5 \%(\mathrm{v} / \mathrm{v})$ phosphoric acid] were obtained from Thermo Scientific Co. (Waltham, MA, USA). 3-(4,5-dimethyl-2-thiazolyl)-2,5diphenyl-2-H-tetrazolium bromide (MTT), 6-hydroxy-2,5,7,8tetramethyl-2- carboxylic Acid (Trolox) powder, acetyl-cholinesterase (AChE), lipopolysaccharide (LPS), $A \beta_{1-40}$ and 2,2'-azobis (2-methylpropanimidamide) dihydrochloride (AAPH) were purchased from Sigma (Shanghai, China). Galanthamine (GLAH), columbamine, jatrorrhizine, tetrandrine, palmatine and berberine were supplied by National Institutes for Food and Drug Control (Beijing, China). There structures are shown in Figure S1. Ultrasonic water bath (Kun Shan, Jiangsu, China) was used for assisting the extraction process. All the samples were collected from Guangxi province (Guangxi, China) and authenticated by Prof. Weixian Deng (Shaoguan University, Guangdong, China) (Table 1).

\section{Sample preparation for extracts solution}

The preparation method for the cultivated M. bealei, wild $M$. bealei and its substitutes were carried out following the Chinese Pharmacopoeia (2020 edition) [19]. Dry above-mentioned raw materials were firstly grounded into powder with a high speed pulverizer and then filtered by 30 mesh sieves. All the selected materials ( $0.25 \mathrm{~g}$ per each) were then transferred to a $150 \mathrm{~mL}$ conical flask with stopper adding $50 \mathrm{~mL} \mathrm{MeOH} / \mathrm{HCl}(100 / 1, \mathrm{v} / \mathrm{v})$ as a solvent. After ultrasonication at room temperature for $45 \mathrm{~min}, \mathrm{MeOH} / \mathrm{HCl}(100 / 1$, $\mathrm{v} / \mathrm{v}$ ) was added to compensate the weight loss during extraction. The solution was then centrifuged at $4000 \mathrm{rpm}$ for $10 \mathrm{~min}$. The supernatant was then evaporated to dryness. Finally, the residue was dissolved with PBS and diluted to a concentration of $3.0 \mathrm{mg} / \mathrm{mL}$ with PBS as well, then filtered through a $0.22 \mu \mathrm{m}$ membrane before use.

\section{Determination of alkaloid compounds from tested extracts}

All separations were carried out on a Waters XBridge C18 column $(4.6 \mathrm{~mm} \times 250 \mathrm{~mm}, 5 \mu \mathrm{m})$ using a gradient with $0.1 \%(\mathrm{v} / \mathrm{v})$ phosphoric acid (A) and ACN (B). A gradient was carried out as follows: $0 \mathrm{~min} / 5 \%$ B, $17 \mathrm{~min} / 17 \% \mathrm{~B}, 35 \mathrm{~min} / 20 \% \mathrm{~B}, 45 \mathrm{~min} / 20 \% \mathrm{~B}, 50 \mathrm{~min} / 23 \% \mathrm{~B}, 60$ $\mathrm{min} / 50 \% \mathrm{~B}, 70 \mathrm{~min} / 50 \% \mathrm{~B}, 70.1-80 \mathrm{~min} / 5 \% \mathrm{~B}$. The injection volume and flow rate were set at $10 \mu \mathrm{L}$ and $1.0 \mathrm{~mL} / \mathrm{min}$, respectively. Besides, the column temperature was set at $25^{\circ} \mathrm{C}$ and $210 \mathrm{~nm}$ was chosen as the detection wavelength. Five alkaloids used as standards were available in our lab including columbamine, jatrorrhizine, tetrandrine, palmatine and berberine. These alkaloids from extracts were identified by their retention time and DAD spectra of standards and quantified using calibration curves.

\section{AChE inhibition assay}

An adapted version of Ellman assay preformed in 96 well plates [18] was applied to test anti-AChE activity of wild $M$. bealei, cultivated $M$. bealei and its substitutes. AChE was dissolved in $0.1 \mathrm{~mol} / \mathrm{L}$ PBS (pH

Table 1. Sample information

\begin{tabular}{|c|c|c|c|}
\hline Species & Abbreviations: & Origin & Specifications \\
\hline $\begin{array}{c}\text { M. bealei } \text { (Fort.) } \\
\text { Carr. }\end{array}$ & ZP & Guangxi & $\begin{array}{c}\text { Crude drugs } \\
\text { (cultivated) }\end{array}$ \\
\hline $\begin{array}{c}\text { M. bealei } \text { (Fort.) } \\
\text { Carr. }\end{array}$ & YS & Guangxi & Crude drugs (wild) \\
\hline $\begin{array}{c}\text { M. breviracema } \text { Y. S. } \\
\text { Wang et Hsiao }\end{array}$ & DX & Guangxi & Crude drugs (wild) \\
\hline $\begin{array}{c}\text { M. duclouxiana } \\
\text { Gagnep }\end{array}$ & CZ & Guangxi & Crude drugs (wild) \\
\hline $\begin{array}{c}\text { M. bodinieri } \text { Gagnep } \\
\text { M. fordii } \text { Schneid }\end{array}$ & XG & Guangxi & Crude drugs (wild) \\
\hline
\end{tabular}


7.4), and those extracts were mixed with $15 \mu \mathrm{L}$ AChE solution (0.303 U/ $\mathrm{mL}$ ) in a 96-well plate. Subsequently, $140 \mu \mathrm{L}$ PBS (0.1 mol/L, $\mathrm{pH} 7.4), 10$ $\mu \mathrm{L}$ DTNB $(3.3 \mathrm{mM})$, and $10 \mu \mathrm{L}$ ATCI $(15 \mathrm{mM})$ were added in sequence then incubated for $10 \mathrm{~min}$ at $37^{\circ} \mathrm{C}$. The absorbance was measured at $405 \mathrm{~nm}$ using a MultiskanTM FC microplate reader. GLAH $(20 \mu \mathrm{M})$ was used as positive control. All extracts were evaporated and re-dissolved in PBS that was used as blank control. The experiment was carried out in triplicates and all samples were measured three times. Potential antiAChE effects were expressed as the percentage of inhibition rate and calculated as follow equation:

Inhibition $(\%)=[1-(\mathrm{Ai}-\mathrm{Ac}) /(\mathrm{A} 0-\mathrm{Ab})] \times 100 \%----(1)$

Where Ai and Ac represent sample with AChE and without AChE. $\mathrm{A} 0$ and $\mathrm{Ab}$ represent PBS with AChE and without AChE.

\section{Cytotoxicity study/A $\beta$ peptide assay}

The PC12 cell, originally derived from a pheochromocytoma of the rat adrenal medulla, is used as a model in neurotoxicity and neuroprotective studies [20]. This study aimed to evaluate the potential neuroprotective activity of six plant extracts by reducing the cytotoxicity of $A \beta_{1-40}$ in PC12 cells. Native, monomeric pre-fibrillar $A \beta_{1-40}$ was prepared at $37^{\circ} \mathrm{C}$ for 7 days by dissolving in PBS to yield a protein concentration of $1 \mathrm{mM}$ and stored at $-20^{\circ} \mathrm{C}$ before use. PC12 cells were cultured in RPMI 1640 medium (Gibco, USA), supplemented with $10 \%$ FBS (Gibco, USA), 1\% penicillin and streptomycin maintaining at $37{ }^{\circ} \mathrm{C}$ under the condition of $5 \% \mathrm{CO}_{2}$. MTT was used to evaluate the cytotoxicity of the selected concentrations of these extracts. The extracts were initially screened at several different concentrations $(7.14,14.28,28.56$ and $57.12 \mu \mathrm{g} / \mathrm{mL})$ to evaluate their toxicity. $100 \mu \mathrm{L}$ cells were seeded at a density of $1.0 \times 10^{4}$ cells in a 96-well plate and incubated overnight. Thereafter, the cells were treated with test extracts for $24 \mathrm{~h}$. At the end of incubation, $20 \mu \mathrm{L}$ of MTT $(5.0 \mathrm{mg} / \mathrm{mL}$, dissolved with DMSO) were added to each well and incubated for another $4 \mathrm{~h}$. $150 \mu \mathrm{L}$ DMSO were added to help dissolve the formazan crystals in each well and slightly shaking the plate to dissolve. The absorbance was measured at $570 \mathrm{~nm}$. The cell viability was calculated as follow:

Cell viability $=($ OD sample - OD blank $) /($ OD control - OD blank $)$ $\times 100 \%-----(2)$

The cell viability has to be determined in order to ensure the selected concentrations of extracts have no significant cytotoxicity and induced cell death. 96-well plates containing density of $1.0 \times 10^{4}$ PC 12 cells per well were treated by different concentration of extracts or PBS in designated wells. The plate was then incubated for $24 \mathrm{~h}$ at $37^{\circ} \mathrm{C}$ with $5 \% \mathrm{CO}_{2}$.

In order to select an optimal concentration for $A \beta_{1-40}$ treatment, cell viability after processing with $A \beta_{1-40}$ was determined using MTT assay. After incubation for $24 \mathrm{~h}$, all the culture media were replaced with $100 \mu \mathrm{L}$ fresh RPMI media and $10 \mu \mathrm{L}$ of various concentration of $\mathrm{A} \beta_{1-40}(1.82,3.62,7.38,16.64,29.55$ and $42.48 \mu \mathrm{M}) .10 \mu \mathrm{L}$ RPMI media was regarded as negative control and incubated for another $48 \mathrm{~h}$ at $37^{\circ} \mathrm{C}$ with $5 \% \mathrm{CO}_{2}$. GALH was used as positive control. Subsequently, the culture media was replaced with serum-free media containing $20 \mu \mathrm{L}$ of MTT $(5.0 \mathrm{mg} / \mathrm{mL}$, dissolved with DMSO). The plate was further incubated for $4 \mathrm{~h}$. All the media then were removed and added 150 $\mu \mathrm{L}$ DMSO to dissolve the formazan crystals. The determination of cell viability sees equation (2).

\section{Oxygen radical absorbance capacity (ORAC) assay}

ORAC assay was applied to evaluate the antioxidant activity for the six plant extracts [21]. This assay is based on the scavenging of peroxyl radicals generated by $\mathrm{AAPH}$, which prevent the degradation of the fluorescein probe. The ORAC assay was performed using a modified method [22], and the concentration of the extracts were optimized in order to compare their difference. AAPH and sodium fluorescein were both dissolved in $75 \mathrm{mM}$ phosphate buffer $(\mathrm{pH} 7.0)$ at the final concentration of $173 \mathrm{mM}$ and $789 \mathrm{nM}$, respectively. $25 \mu \mathrm{L}$ of extracts at optimal concentration and $100 \mu \mathrm{L}$ sodium fluorescein were added into black-walled 96-well plate and pre-incubated for $10 \mathrm{~min}$ at $37^{\circ} \mathrm{C}$. Subsequently, $75 \mu \mathrm{L}$ AAPH was added and their fluorescence for all test were recorded $3 \mathrm{~h}$ at excitation and emission wavelengths of $485 \mathrm{~nm}$ and $515 \mathrm{~nm}$ every $2 \mathrm{~min}$. A blank sample contained the same reaction mix and PBS instead of extracts sample. Five calibration solutions of Trolox $(0,3.125,6.25,12.5$ and $25 \mu \mathrm{g} / \mathrm{mL})$ were used to establish a standard curve for calculating their ORAC values. The results were expressed as Trolox Equivalents (TE) in $\mu \mathrm{mol}$ per g extract ( $\mu \mathrm{M} \mathrm{TE} / \mathrm{g}$ ). All samples were analyzed in triplicate.

\section{Anti-inflammatory assays}

Cell cultures and cell viability: LPS-induced RAW 264.7 macrophages has been widely used as in vitro models in studies related to inflammation [23]. RAW 264.7 cells were grown in DMEM media containing $10 \% \mathrm{FBS}, 100 \mathrm{U} / \mathrm{mL}$ penicillin and $100 \mu \mathrm{g} / \mathrm{mL}$ streptomycin in a humidified incubator containing $5 \% \mathrm{CO}_{2}$ at $37^{\circ} \mathrm{C}$. In brief, the $160 \mu \mathrm{L}$ RAW264.7 cells were cultured in 96-well plates at a density of $1.0 \times 10^{5}$ cells per well for $4 \mathrm{~h}$. Thereafter, the cells were treated with 20 $\mu \mathrm{L}$ plant extracts at different concentrations $(1.95,3.9,7.8,15.6,31.2$, 62.5 and $125 \mu \mathrm{g} / \mathrm{mL})$ and $20 \mu \mathrm{L}$ of LPS $(1.0 \mu \mathrm{g} / \mathrm{mL})$. The control wells were treated with or without LPS. After $24 \mathrm{~h}$ of incubation, $20 \mu \mathrm{L} 10 \%$ CCK-8 solutions (dissolved in DMEM media) were added to each well and further incubated for additional $2 \mathrm{~h}$ at $37^{\circ} \mathrm{C}$. All the experiments were carried out in triplicate. The value of optical density (OD) was determined at $450 \mathrm{~nm}$ wavelength and cell viability was calculated as the equation (2).

Nitric oxide (NO) assay: RAW264.7 cells were seeded at density of $1.0 \times 10^{5}$ cells per well and incubated with or without LPS $(1.0 \mu \mathrm{g} /$ $\mathrm{mL}$, dissolved and diluted with PBS) in the absence or presence of various concentration $(3.9,7.8,15.6,31.2$ and $62.5 \mu \mathrm{g} / \mathrm{mL})$ for $24 \mathrm{~h}$. The cell culture supernatants were collected. Aliquots $(50 \mu \mathrm{L})$ of culture supernatants were mixed with equal volume of Griess reagent and incubated at room temperature for $10 \mathrm{~min}$. Absorbance were measured at $540 \mathrm{~nm}$ using a microplate reader. A series of sodium nitrite $(0,10$, $20,40,60,80$ and $100 \mu \mathrm{M}$ ) was served as standards.

Enzyme-linked immunosorbent assay (ELISA): The amount of TNF-a in cell culture supernatants was quantified by using an ELISA kit and operation was performed according to the manufacture's protocol. The absorbance was recorded by using a microplate reader at $540 \mathrm{~nm}$ wavelength.

\section{Statistical analysis}

All the experiments were repeated three times. The results were expressed as means \pm standard deviation (SD). Statistical significance was calculated to compare treated and control groups and determined by Student's t-tests or one-way analysis of variance (ANOVA). A value of $p<0.05$ or $p<0.01$ was considered as significant. The statistical analysis was carried out using GraphPad Prism software (Version 8.0, GraphPad Software, Inc., La Jolla, CA, USA). 


\section{Results}

\section{Determination of five alkaloids in six plant extracts}

Ten milligrams of each standard compound were accurately weighed and put into a $10 \mathrm{~mL}$ volumetric flask, and then dissolved with pure $\mathrm{MeOH}$. Further solutions were prepared by serial dilutions with the same solvent to obtain their calibrated curves. Satisfactory results were obtained for the five alkaloid compounds tested, including correlation coefficients higher than 0.999 (Table S1). As shown in Figure 1, a satisfactory separation for the five alkaloids was observed. Thereafter, the assays of these five alkaloids from those six plant extracts were determined and the results were listed in Table 2 . The concentration of palmatine is the highest for all the extracts while tetrandrine has the lowest content among the test alkaloids. The total contents for five alkaloids from those six extracts are decreased as follows: wild $M$. bealei $(\mathrm{YS}, 520.6 \mu \mathrm{g} / \mathrm{mL})>\mathrm{CZ}(323.98 \mu \mathrm{g} / \mathrm{mL})>\mathrm{BJ}(260.85 \mu \mathrm{g} / \mathrm{mL})>\mathrm{DX}$ $(212.90 \mu \mathrm{g} / \mathrm{mL})>\mathrm{XG}(183.95 \mu \mathrm{g} / \mathrm{mL})>$ cultivated M. bealei $(\mathrm{ZP}, 130.05$ $\mu \mathrm{g} / \mathrm{mL})$.

\section{Effects of extracts on AChE activity}

Based on our previous study [13], the extract of M. bealei showed a good inhibition of AChE activity. Since their quality difference of the cultivated M. bealei, wild M. bealei and its substitute were successfully confirmed, while the anti-AChE activity for these plants were still unknown. Therefore, the investigation on their anti-AChE activities was carried out. The result was shown in Figure 2, the inhibition of AChE ranked as wild $M$. bealei (YS, 81\%) > cultivated M. bealei (ZP, 78.2\%) $>\mathrm{XG}(76.8 \%)>\mathrm{CZ}(75.8 \%)>\mathrm{BJ}(73.4 \%)>\mathrm{DX}(68.5 \%)$. Comparing to the positive control (GALH), all the extracts exhibited a higher AChE

Table 2. Concentration $(\mu \mathrm{g} / \mathrm{mL})$ of five alkaloids in six plant extracts

\begin{tabular}{|c|c|c|c|c|c|c|}
\hline Samples & \multicolumn{7}{|c|}{ Alkaloids content $(\boldsymbol{\mu g} / \mathbf{m L})(\mathbf{n}=\mathbf{3})$} \\
\hline & Columbamine & Jatrorrhizine & Tetrandrine & Palmatine & Berberine & Total \\
\hline ZP & 9.28 & 25.74 & 5.34 & 54.57 & 35.12 & 130.05 \\
\hline YS & 6.45 & 49.91 & ND & 282.44 & 181.80 & 520.60 \\
\hline DX & 4.43 & 25.46 & 3.53 & 109.19 & 70.28 & 212.90 \\
\hline CZ & 4.76 & 11.24 & 9.29 & 181.72 & 116.97 & 323.98 \\
\hline XG & 7.24 & 12.50 & 5.89 & 96.32 & 62.00 & 183.95 \\
\hline BJ & 10.51 & 63.08 & 3.62 & 111.72 & 71.91 & 260.85 \\
\hline
\end{tabular}

ND: not detected

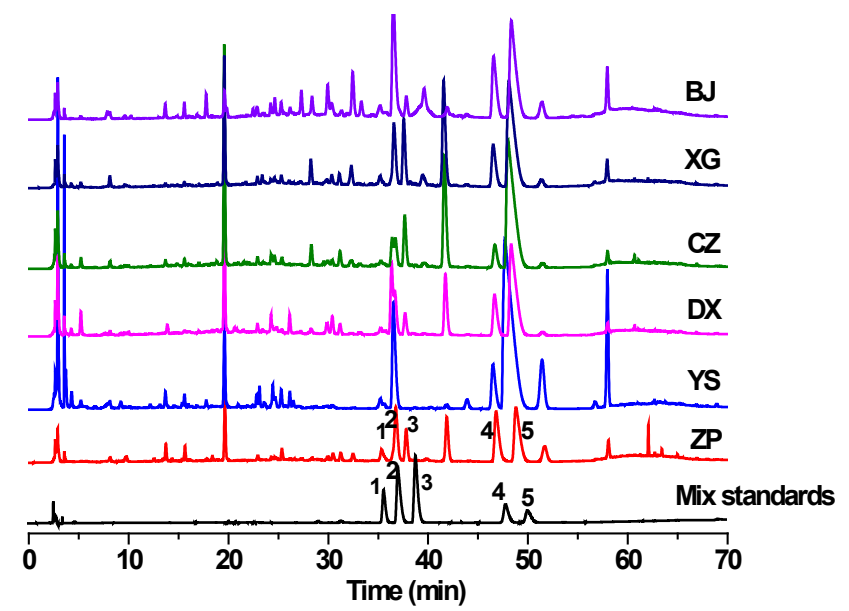

Figure 1. HPLC chromatograms of six plant extracts and mixed standards. Compounds: 1 . Columbamine, 2. Jatrorrhizine, 3. Tetrandrine, 4. Palmatine, 5. Berberine

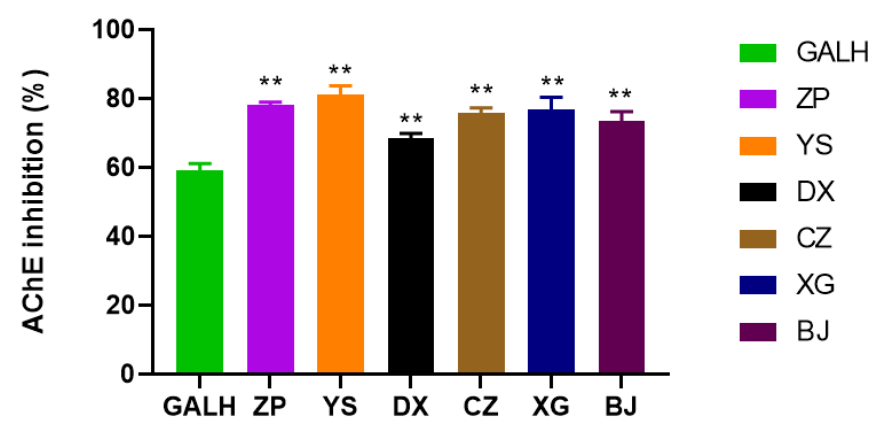

Figure 2. AChE inhibition by six plant extracts (ZP, YS, DX, CZ, XG and BJ) and GALH. GALH was used as positive control. Data were shown as means \pm SD $(n=3)$

inhibition. The overall anti-AChE trend is wild M. bealei > cultivated M. bealei $>$ substitutes.

\section{Cell viability and optimal concentration of $A \beta_{1-40}$ for cell model}

The cell viability of selected plant extracts at different concentrations $(7.14,14.28,28.56$ and $57.12 \mu \mathrm{g} / \mathrm{mL})$ was evaluated in PC 12 cells by MTT assay (Figure S2). The results showed all levels of extracts present good cell viability (higher than $80 \%$ ), it demonstrated all selected concentrations had relatively low cytotoxicity on PC12 cell. The $57.12 \mu \mathrm{g} / \mathrm{mL}$ was subsequently selected as optimal concentration in neuroprotective assay. Afterwards, PC12 cells were treated with different concentrations of $A \beta_{1-40}$, and the percentage of surviving cells was determined using a MTT to create a cell model of AD. Compared with control group, the growth of a greater percentage of cells was inhibited as the $A \beta_{1-40}$ concentration increased. It was found that a significant difference between $29.55 \mu \mathrm{M} \mathrm{A} \beta_{1-40}$ group and control group ( $p<0.01$ ) was observed with a cell viability reduction of $63 \%$ in the MTT assay (Figure S3). Based on the results, the cell model was successfully established under the concentration of $29.55 \mu \mathrm{M}$ of $\mathrm{A} \beta_{1-40}$ and was selected as further investigation.

\section{Neuroprotective activity of extracts against $A \boldsymbol{\beta}_{1-40}$}

GALH has been proved to have neuroprotective effect against $\mathrm{A} \beta_{1-40}$ and was prescribed to AD patients with mild and moderate dementia [24]. In this assay, GALH was used as positive control, and the PC12 cells were treated with $29.55 \mu \mathrm{M} \mathrm{A} \beta_{1-40}$ and co-incubated with $57.12 \mu \mathrm{g} / \mathrm{mL}$ of different extracts or GALH for $48 \mathrm{~h}$. Compared to the control group, the cell viability in the model group significantly decreased. With the addition of extracts, survival rate was significantly higher than control and $A \beta_{1-40}$ alone. The results showed the extracts reduced the toxicity induced by $A \beta_{1-40}(\mathrm{p}<0.05)$, indicating these plant extracts had neuroprotective activity. Their neuroprotective effects were in the following decreasing order: YS $(71 \%)>\mathrm{ZP}(68 \%)>\mathrm{CZ}(67 \%)>$ XG $(66 \%)>$ DX $(65.2 \%)>$ BJ (64\%) (Figure 3).

\section{Effect of extracts on antioxidant activity}

The mechanism of ORAC assay is that antioxidant inhibits peroxyl radical-induced oxidation, and then the peroxyl radicals are generated by AAPH. Thereafter, the fluorescent intensity of oxidation substrate is measured [25]. The values of their antioxidant ability are expressed as relative value to standard (Trolox) antioxidant activity. In order to measure the ORAC values of different plant extracts, a representative and dynamic fluorescence curve were plotted in Figure S4. The linear standard curve equation was calculated as $\mathrm{Y}=56208 \mathrm{X}\left(\mathrm{R}^{2}=0.9486\right)$. 
The fluoresence intensity of various concentrations of Trolox was recorded at $2 \mathrm{~min}$ intervals within $3 \mathrm{~h}$ by using microplate reader and each data point was plotted in Figure S5. The relative fluorescence intensity was decreased with time-consuming while the ORAC values increased with higher standard concentrations.

Before the experiment was carried out, the concentration of cultivated M. bealei extract $(50,100$ and $150 \mu \mathrm{g} / \mathrm{mL})$ was optimized. The results were depicted in Figure S6. Fluorescence intensity for all extracts were fully attenuated to zero within $3 \mathrm{~h}$ under the concentration of 100 $\mu \mathrm{g} / \mathrm{mL}$ while the other two concentrations could not reach zero for all the extract within $3 \mathrm{~h}$. Therefore, the concentration at $100 \mu \mathrm{g} / \mathrm{mL}$ was selected as the optimal concentration for the activity comparison of each extract.

Under this optimal concentration, the fluorescence attenuation for all the extracts could be observed in the curves. With the higher net area under the curve, the antioxidant activity present much stronger. Compared to the selected concentration of Trolox $(3.125 \mu \mathrm{g} / \mathrm{mL})$, the results showed all the extracts present a good antioxidant activity (Figure 4). The antioxidant activity of the extracted samples was in the following decreasing order: $\mathrm{YS}>\mathrm{ZP}>\mathrm{XG}>\mathrm{CZ}>\mathrm{DX}>\mathrm{BJ}$.

ORAC values for all the plant extracts were also calculated and expressed as Relative Trolox Value. As shown in Figure 5, YS extract showed the highest ORAC value among different extracts, indicating a considerably higher antioxidant activity than other extracts. The

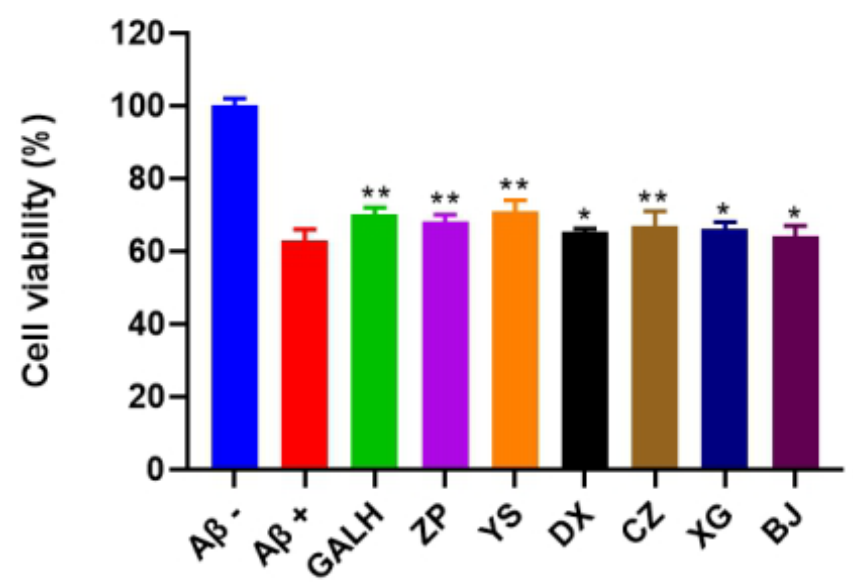

Figure 3. Cell viability of six plant extracts (ZP, YS, DX, CZ, XG and BJ) and GALH on $\mathrm{A} \beta_{1-40}$ treated PC12 cells. GALH was used as positive control. A $\beta$-group: no treatment of $\mathrm{A} \beta_{1-40}$ and extracts; $\mathrm{A} \beta+$ group: only treated with $29.55 \mu \mathrm{M} \mathrm{A} \beta_{1-40}$. Data were shown as means $\pm \mathrm{SD}(\mathrm{n}=3)\left({ }^{*} \mathrm{p}<0.05, * * \mathrm{p}<0.01\right.$ compared to the control $)$

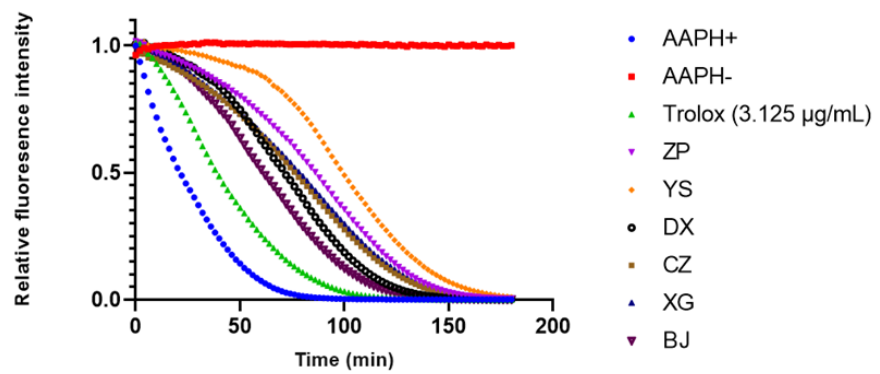

Figure 4. Effect of six plant extracts (ZP, YS, DX, CZ, XG and BJ) and Trolox (3.125 $\mu \mathrm{g}$ / $\mathrm{mL}$ ) on fluorescence attenuation curve in concentration response. All six plant extracts were prepared in $\mathrm{MeOH}$ and same volume of $\mathrm{MeOH}$ was added into APPH- (negative control). Data were shown as means $(n=3)$

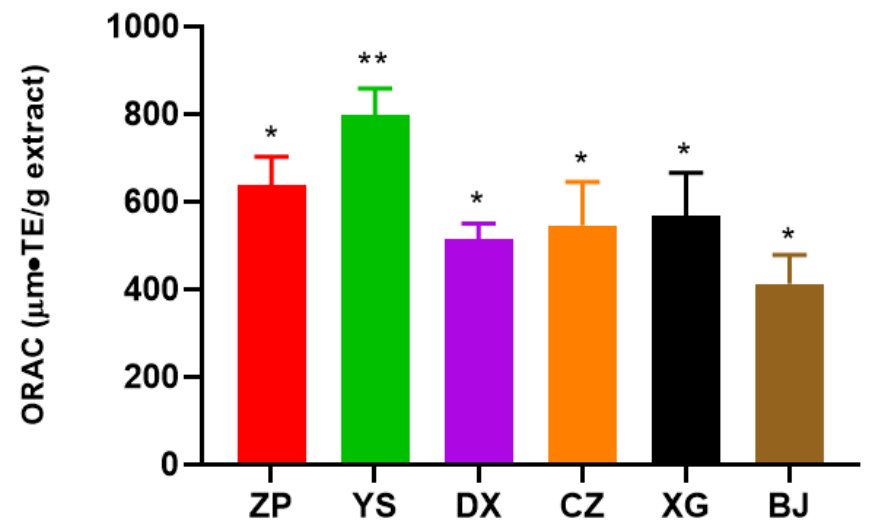

Figure 5. Relative Trolox value of six plant extracts (ZP, YS, DX, CZ, XG and BJ) at concentration $100 \mu \mathrm{g} / \mathrm{mL}$. The unit of relative Trolox value is $\mu \mathrm{mol} \mathrm{TE} / \mathrm{g}$. Data were shown as means $\pm \operatorname{SD}(\mathrm{n}=3)$

antioxidant potency of extracts was ranked as follows: YS $(797.8 \mu \mathrm{mol}$ $\mathrm{TE} / \mathrm{g})>\mathrm{ZP}(636.8 \mu \mathrm{M} \mathrm{TE} / \mathrm{g})>\mathrm{XG}(567.8 \mu \mathrm{M} \mathrm{TE} / \mathrm{g})>\mathrm{CZ}(546.5 \mu \mathrm{M}$ $\mathrm{TE} / \mathrm{g})>\mathrm{DX}(515.1 \mu \mathrm{M} \mathrm{TE} / \mathrm{g})>\mathrm{BJ}(413.1 \mu \mathrm{M} \mathrm{TE} / \mathrm{g})$.

\section{Effect of extracts on RAW264.7 cell viability}

The results of cell viability of RAW 264.7 cells were illustrated in Figure S7, cell viability were all higher than $90 \%$ after treating RAW 264.7 cells with extracts at different concentrations $(1.95-125 \mu \mathrm{g} / \mathrm{mL})$ indicating these concentrations of extract did not affect the viability of the RAW 264.7 cells and could be applied for further investigations. In fact, $\mathrm{Hu}$ et al. [16] compared the toxic effect of fractions of n-hexane, $\mathrm{CH}_{2} \mathrm{Cl}_{2}, \mathrm{n}-\mathrm{BuOH}$, or water and ethanol at the concentration of $100 \mu \mathrm{g} /$ $\mathrm{mL}$ indicating that only ethanol fraction induced marked cytotoxicity in the LPS-stimulated RAW264.7cells. Although the solvent of $\mathrm{MeOH}-$ $\mathrm{HCl}$ wasn't investigated during their research, our results gave a complementary result under the concentration of $125 \mu \mathrm{g} / \mathrm{mL}$.

\section{Effect of extracts on NO and TNF-a production}

LPS-stimulated RAW 264.7 macrophages produce excessive inflammatory mediators and pro-inflammatory cytokines and act as an experimentally convenient model to evaluate the anti-inflammatory activity of drug candidates [26]. In response to LPS stimulation, macrophages could release pro-inflammatory cytokines, such as NO and TNF-a. In this experiment, the RAW264.7 cells were treated with LPS in the presence or absence of extracts. The levels of NO and TNF-a were measured by Griess reaction and ELISA kit respectively to assess their anti-inflammatory properties. Because NO is an important inflammatory cytokine produced by iNOS and is primarily involved in promoting inflammatory responses. Its excess production can lead to cell death, inflammation, and autoimmune disorders [27]. In order to select an appropriate concentration for the inflammatory comparison of those plant extracts, several representative concentrations $(3.90,7.80$, 15.6, 31.2 and $62.5 \mu \mathrm{g} / \mathrm{mL}$ ) of ZP extract was selected. Sodium nitrite standard curve was plotted to calculate the NO production of each group, the calibration range set up as $0,10,20,40,60,80$ and $100 \mu \mathrm{M}$ to establish a standard curve of $\mathrm{Y}=0.0098 \mathrm{X}\left(\mathrm{R}^{2}=0.977\right)$ (Figure S8). The amounts of $\mathrm{NO}$ were determined via the Griess reaction. As presented in Figure S9, after treatment of LPS, NO production in the cell culture medium increased markedly with the increasing concentration of $\mathrm{ZP}$ extract. It was found that there was a statistically significant difference of reducing NO production between non-treatment group with the concentration of $7.80 \mu \mathrm{g} / \mathrm{mL}$ group, thus, the concentration of $7.80 \mu \mathrm{g} /$ $\mathrm{mL}$ was selected for following experiment. 
Subsequently, the NO and TNF- $\alpha$ production of all extracts were determined in LPS-stimulated RAW 264.7 cell. As shown in Figure 6, the extract exhibited a high potential in modulating inflammatory reactions through inhibiting NO production. The anti-inflammatory ability of extracts was ranked as follow: YS $(21.37 \mu \mathrm{M})>\mathrm{ZP}(23.28 \mu \mathrm{M})$ $>$ DX $(25.1 \mu \mathrm{M})>$ BJ $(27.4 \mu \mathrm{M})>$ XG $(27.9 \mu \mathrm{M})>\mathrm{CZ}(30.23 \mu \mathrm{M})$ (wild M. bealei $>$ cultivated $M$. bealei $>$ substitutes).

Previous reports have concluded that TNF- $\alpha$ is a critical factor that regulate pro-inflammatory cytokines and mediate inflammatory response [28]. To evaluate whether the production of TNF- $\alpha$ was suppressed by the treatment of those extracts in LPS-stimulated RAW 264.7 cell, the determination of TNF- $\alpha$ in the cell culture supernatant were investigated by the ELISA kit. The values of TNF- $\alpha$ production were calculated basing on the logistic curve of TNF- $\alpha$ at different standard concentrations. As shown in Figure 7, those extracts significantly decreased the levels of TNF- $\alpha$ production compared to the control group, indicating that inflammatory response was suppressed by the treatment of analyzed extracts. The amount of TNF- $\alpha$ production was in the following decreasing order: YS $(65.6 \mathrm{ng} / \mathrm{mL})>\mathrm{ZP}(89.4 \mathrm{ng} /$ $\mathrm{mL})>\mathrm{DX}(123.8 \mathrm{ng} / \mathrm{mL})>\mathrm{CZ}(146.3 \mathrm{ng} / \mathrm{mL})>\mathrm{BJ}(169.2 \mathrm{ng} / \mathrm{mL})>\mathrm{XG}$ $(171.5 \mathrm{ng} / \mathrm{mL})$.

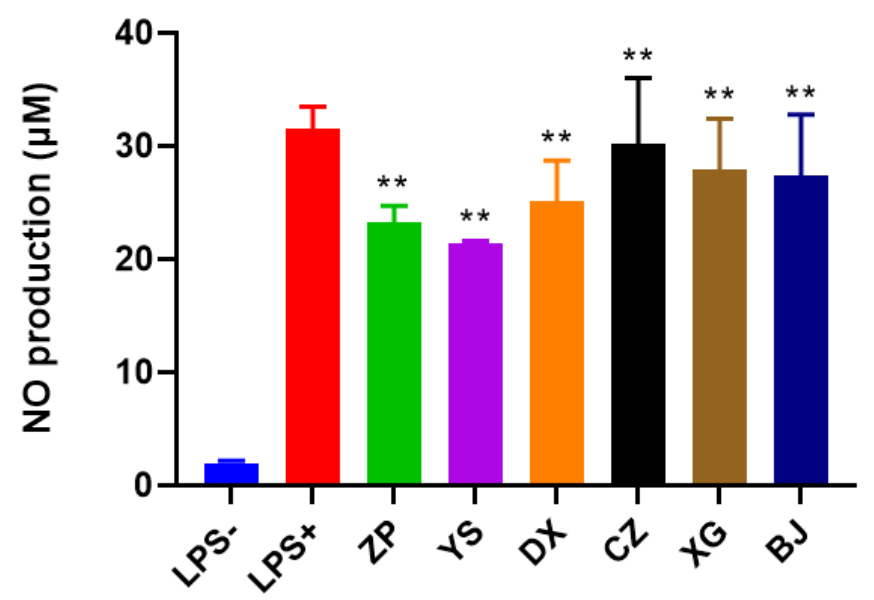

Figure 6. NO production after the treatment of six plant extracts (ZP, YS, DX, CZ, XG and BJ) for $24 \mathrm{~h}$ in LPS-induced RAW264.7 cell. All extracts were diluted to $7.80 \mu \mathrm{g} / \mathrm{mL}$ by PBS. Data were shown as means $\pm \mathrm{SD}(\mathrm{n}=3)$. ** $\mathrm{p}<0.01$ compared to control or cells treated with LPS alone

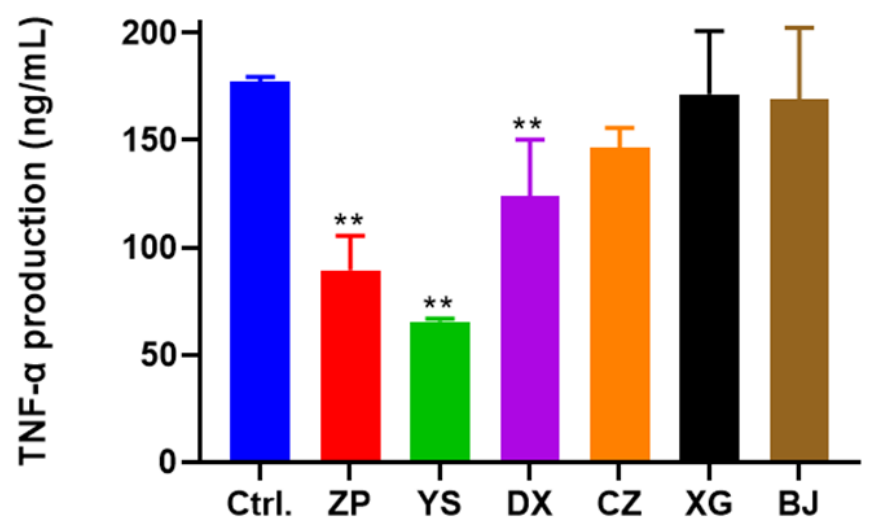

Figure 7. TNF- $\alpha$ production after the treatment of six plant extracts (ZP, YS, DX, CZ, XG and BJ) for $24 \mathrm{~h}$ in LPS-induced RAW264.7 cells. All extracts were diluted to $7.80 \mu \mathrm{g} / \mathrm{mL}$ control (Ctrl.) group was added same amount of DMEM instead of treatment of extracts. Data were shown as means $\pm \mathrm{SD}(\mathrm{n}=3) . * * \mathrm{p}<0.01$ compared to control or cells treated with LPS alone

\section{Discussion}

Alkaloids are regarded as the major constituents of Mahonia species and mainly responsible for most of the properties shown by these plants. Five alkaloids were selected as investigation to determine the content difference of those six plant extracts. These chemical constituents belonging to indole alkaloids are generally helpful in elucidating their pharmacological activities. It was found that indole alkaloids present a close relation with anti-AD by exhibiting significant AChE inhibitory activity [29], anti-inflammatory [30], antioxidant [31]. It's noted that the contents of alkaloids from ZP (cultivated one) were less than YS or the substitutes (wild one). The result might due to the different cultivation environment resulting in a difference of chemical content compared to the wild growing environment [14]. Subsequently, their anti-AD activity was evaluated and compared. The results indicated an overall trend for all the investigated activities (anti-AChE, anti-A $\beta_{1-40}$, antioxidant and anti-inflammatory activity) was as following decreasing order: wild $M$. beale $i>$ cultivated $M$. beale $i>$ substitutes. Interestingly, investigated wild $M$. bealei and cultivated $M$. bealei extracts belonging to authentic products are documented in Chinese Pharmacopoeia. Several local drug standards from China claimed that those substitutes can replace authentic plant for medicine use [32,33]. However, based on our results, there is a markedly different activity between authentic products and substitutes indicating that those authentic products could not be replaced with substitutes in medical use. Additionally, their activity results are not fully related to the contents of five alkaloids that further confirm other constituents from these plants may also contribute the $\mathrm{AD}$ activity. It also demonstrated those effects are caused in a holistic way with its multiple components and multiple targets of these extracts. Moreover, it was worth noting that there was also slightly different effect between each substitute in the activity test, for example, $\mathrm{XG}$ has higher anti-AChE, anti-A $\beta$ and antioxidant activity than $\mathrm{BJ}$, while $\mathrm{BJ}$ showed stronger anti-inflammatory potency than XG. Although the content of five alkaloids in BJ $(260.85 \mu \mathrm{g} / \mathrm{mL})$ present higher than XG $(183.95 \mu \mathrm{g} / \mathrm{mL})$, it seemingly showed that the alkaloids content is positively correlated with anti-inflammatory activity instead of other three selected effects. It also indicated that those plant extracts alleviated LPS-induced RAW 264.7 cell immune response probably by inhibiting the production of NO and TNF- $\alpha$. The possible explanation might be the different chemical constitutions mechanisms of selected activity tests are observed which finally leads to their bio-activity distinction. Compared to the recent literature, $M$. beale $i$ had been proved to exert many activities such as antioxidant [17], anti-inflammatory [16] and anti-AChE [18]. It was worth noting that our results also indicated those effects were obtained on the extract of $M$. bealei, which are closely related with AD disease.

\section{Conclusions}

Based on the results obtained in this study, all the extracts including wild $M$. bealei, cultivated $M$. bealei and its substitutes showed the significant activity of anti-AChE, anti- $\mathrm{A} \beta$, antioxidant and antiinflammatory. The overall potency trend for the selected extracts was ranked as follows: wild $M$. bealei > cultivated $M$. bealei > substitutes. In our previous study, the overall effect of $M$. bealei extract showed greater anti-AChE effect than the sum of several isolating single compounds from plant. It further confirmed that TCM extract treats or prevents illness acting as a comprehensive medical system instead of combining several isolating single compounds from the plant. It also demonstrated that the use of the extracts of $M$. bealei can be a promising candidate for the treatment of AD. Moreover, in both cell viability study on PC12 and RAW264.7, the extracts did not show significant cytotoxicity. It showed great potential that these crude extracts exert a good effect 
on $\mathrm{AD}$ treatment. However, more in-depth studies aimed at in vivo investigation of the extracts should be assessed or mechanisms of protein expression or signaling pathway are still required to elucidate.

\section{Funding}

This work was supported by the financial support from China Postdoctoral Science Foundation (2018M643205) and Shenzhen Municipal Science and Technology Innovation Committee (JCYJ20190806171605522).

\section{Declaration of interest}

The authors have declared no conflict of interest.

\section{Acknowledgments}

We gratefully appreciate the financial support from China Postdoctoral Science Foundation (2018M643205) and Shenzhen Municipal Science and Technology Innovation Committee (JCYJ20190806171605522).

\section{References}

1. Webers A, Heneka MT, Gleeson PA (2020) The role of innate immune responses and neuroinflammation in amyloid accumulation and progression of Alzheimer's disease. Immunol Cell Biol 98: 28-41. [Crossref]

2. Balsinha C, Gonçalves-Pereira M, Iliffe S, Freitas JA, Grave J (2019) Health-Care delivery for older people with dementia in primary care. Prim Care Ment Heal Older People 311-329.

3. Singh M, Kaur M, Kukreja H, Chugh R, Silakari O (2013) Acetylcholinesterase inhibitors as Alzheimer therapy: From nerve toxins to neuroprotection. Eur J Med Chem 70: 165-188

4. Coman H, Nemeş B (2017) New therapeutic targets in Alzheimer's disease. Int $J$ Gerontol 11: 2-6.

5. Jiang Y, Gao H, Turdu G (2017) Traditional Chinese medicinal herbs as potential AChE inhibitors for anti-Alzheimer's disease: A review. Bioorg Chem 75: 50-61.

6. Yang WT, Zheng XW (2017) Chinese herbal medicine for Alzheimer's disease: Clinical evidence and possible mechanism of neurogenesis. Biochem Pharmacol 141: 143-155. [Crossref]

7. Su Y, Wang Q, Wang C, Chan K, Sun Y (2014) The treatment of Alzheimer's disease using Chinese medicinal plants: from disease models to potential clinical applications. J Ethnopharmacol 152: 403-423.

8. Dey A, Bhattacharya R, Mukherjee A (2017) Natural products against Alzheimer's disease: Pharmaco-therapeutics and biotechnological interventions. Biotechnol Adv 35 : 178-216.

9. Damar U, Gersner, Johnstone JT (2016) A as a neuroprotective and antiepileptic drug: a review of preclinical research. Expert Rev Neurother 16: 671-680.

10. Howes MJR, Perry E (2011) The role of phytochemicals in the treatment and prevention of dementia. Drugs Aging 28: 439-468. [Crossref]

11. Nordberg A, Svensson AL (1998) Cholinesterase inhibitors in the treatment of Alzheimer's disease: a comparison of tolerability and pharmacology. Drug Saf 19: 465-480.

12. Tu Y (2011) The discovery of artemisinin (qinghaosu) and gifts from Chinese medicine. Nat Med 17: 1217-1220.

13. Huang Y, Wang T, Wang J, Yin G, Tu J (2020) Ligand fishing and identification of acetylcholinesterase inhibitors in Mahonia bealei (Fort) Carr. using high performance liquid chromatography-mass spectrometry. J Liq Chromatogr Relat Technol 43: 538-546.
14. Huang Y, Jiang Z (2019) Quality evaluation of mahonia bealei (Fort.) carr. using supercritical fluid chromatography with chemical pattern recognition. Molecules 24: 3684-3696

15. Li AR, Zhu Y, Li XN, Tian XJ (2007) Antimicrobial activity of four species of Berberidaceae. Fitoterapia 78: 379-381.

16. Hu W, Wu L, Qiang Q, Ji L (2016) The dichloromethane fraction from Mahonia beale (Fort.) Carr. leaves exerts an anti-inflammatory effect both in vitro and in vivo. $J$ Ethnopharmacol 188: 134-143.

17. Hu W, Yu L, Wang MH (2011) Antioxidant and antiproliferative properties of water extract from Mahonia bealei (Fort.) Carr. leaves, Food Chem. Toxicol 49: 799-806.

18. Kaufmann D, Dogra AK, Tahrani A (2016) Extracts from traditional Chinese medicinal plants inhibit acetylcholinesterase, a known Alzheimer's Disease target. Molecules 21: 1161-1177.

19. Chinese Pharmacopoeia Commission (2020) Pharmacopoeia of People's Republic of China, Beijing. China 87.

20. Sun L, Guo C, Liu D (2011) Protective effects of bone morphogenetic protein 7 against amyloid-beta induced neurotoxicity in PC12 cells. Neuroscience 184: 151-163.

21. Cao G, Prior RL (1999) Measurement of oxygen radical absorbance capacity in biological samples. Methods Enzymol 299: 50-62.

22. Akter J, Hossain MA, Takara K, Islam MZ, Hou DX (2019) Antioxidant activity of different species and varieties of turmeric (Curcuma spp): Isolation of active compounds. Comp Biochem Physiol Part - C Toxicol Pharmacol 215: 9-17.

23. Cheng L, Ren Y, Lin D (2019) The Anti-Inflammatory properties of citrus wilsoni tanaka extract in LPS-Induced RAW 264.7 and primary mouse bone marrow-derived dendritic cells. Molecules 22: 1213-1227.

24. Sadeghi L, Yousefi Babadi Y, Tanwir F (2018) Improving effects of Echium amoenum aqueous extract on rat model of Alzheimer's disease. J Integr Neurosci 17: 661-669.

25. Price JA, Sanny CG, Shevlin D (2006) Application of manual assessment of oxygen radical absorbent capacity (ORAC) for use in high throughput assay of "total" antioxidant activity of drugs and natural products. J Pharmacol Toxicol Methods 54: 56-61. [Crossref]

26. Kim HS, Park JW, Kwon OK, Kim JH (2014) Anti-inflammatory activity of a methanol extract from Ardisia tinctoria on mouse macrophages and paw edema. Mol Med Rep 9: $1388-1394$

27. Xu J, Zhao Y, Aisa HA (2017) Anti-inflammatory effect of pomegranate flower in lipopolysaccharide (Lps)-stimulated raw264.7 macrophages. Pharm Biol 55: 20952101.

28. Zhou M, Xu R, Kaelber DC (2020) Tumor Necrosis Factor (TNF) blocking agents are associated with lower risk for Alzheimer's disease in patients with rheumatoid arthritis and psoriasis. PLoS One 15: 1-23.

29. Zhan GQ (2020) Monoterpene indole alkaloids with acetylcholinesterase inhibitory activity from the leaves of Rauvolfia vomitoria. Bioorg Chem 102: 104136-104146.

30. Yuan HL, Zhao YL (2020) Anti-inflammatory and analgesic activities of Neolamarckia cadamba and its bioactive monoterpenoid indole alkaloids. J Ethnopharmacol 260: 113103-113113.

31. Dáfiner P (2019) Antinociceptive and antioxidant effects of extract enriched with active indole alkaloids from leaves of Tabernaemontana catharinensis A. DC. $J$ Ethnopharmacol 239: 111863-111875. [Crossref]

32. Guizhou Provincial Health Department (2003) Quality Standard of National Chinese Herbal Medicines in Guizhou Province; DB52/YC005-2003 Guizhou. China 7.

33. Guangxi Medical Products Administration (2011) Quality Standard of Zhuang Medicine in Guangxi Zhuang Autonomous Region; DYB45-GXZYC0047-2011 Guangxi. China 2: 75-76.

Copyright: (C2021 Huang Y. This is an open-access article distributed under the terms of the Creative Commons Attribution License, which permits unrestricted use, distribution, and reproduction in any medium, provided the original author and source are credited. 